\title{
SiM
}

\section{Elk and Cattle Grazing Can Be Complementary}

\section{Elk Response to a 19-Year Exclusion of Cattle Grazing}

\author{
By Beth Burritt and Roger Banner
}

\section{On the Ground}

- In 1990, cattle grazed private land in Utah's Book Cliff Mountains until late July. Elk in the area ate about $50 \%$ of the forage regrowth on this land from late July to mid-September.

- This private land mentioned was sold in 1990 and managed for elk. At the same time cattle were permanently removed from the area.

- By 2009 , repeat photography showed that vegetation in the area had changed and was dominated by dense stands of mature vegetation and weeds. In 2009 there were no signs of elk, whereas in 1990 many elk and signs of elk were observed in the area.

- Based on this study and many others, carefully managed cattle grazing can be a lost-cost method to improve forage quality for elk.

Keywords: cattle, elk, grazing, competition, rancher, wildlife, livestock.

Rangelands 35(1):34-39

doi: 10.2111/RANGELANDS-D-12-00068.1

(C) 2013 The Society for Range Management

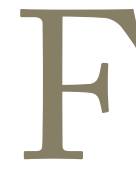

or decades, many wildlife managers and livestock producers disagreed about the impact livestock grazing has on forage for wildlife. A little over 20 years ago, one ranch family grazed their cattle on their private land as well as on a portion of Utah's State Trust Lands known as The State Roadless Area (TSRA) in the remote Book Cliffs Mountains of Utah (Fig. 1). Ranchers who grazed their cattle in TSRA wanted to know how elk affected the amount of forage for their cattle on their private land and how their private land contributed to elk forage and habitat.

In Utah, ranchers receive elk hunting permits to compensate them for elk grazing on their private land. However, these ranchers who owned private land adjacent to TSRA did not feel adequately compensated in terms of landowner elk permits for the following reasons: 1) permits were based on average forage production of both private and state land; 2) most of the private lands owned by ranchers were located along riparian areas, which were much more productive that the adjacent uplands in TSRA; 3) ranchers felt cattle grazing in early summer created high-quality forage for elk in the fall. On the other hand, state wildlife managers felt that cattle were reducing the amount of forage for elk.

In fall of 1990, local ranchers and Utah State University Extension personnel surveyed the area to determine 1) the amount of vegetative regrowth that occurred on private land after cattle grazed the area in early summer and 2) the quantity of forage used by elk on private land in late summer and fall. We planned to return to the area the following spring to determine the amount of forage used by elk on private lands before cattle began grazing in the spring.

Before the survey could be conducted in spring of 1991, 7,500 acres of private land adjoining TSRA was sold to The Nature Conservancy and the Rocky Mountain Elk Foundation. They in turn donated the land to the State of Utah to be managed for elk. The Utah Division of Wildlife Resources removed cattle from the area to improve habitat for elk. Cattle have not grazed the area since 1990.

In late July 2009, researchers and ranchers returned to the same survey locations to see what changes, if any, occurred on the formerly private lands that once supported cattle grazing. They also took photos of each survey location to compare them with photos taken 19 years earlier in July and September 1990. Our study examines the effects of early summer cattle grazing on forage used by elk in late summer and early fall and documents the effect of long-term exclusion of cattle grazing on meadow vegetation in the Book Cliffs Mountains.

\section{Utah's Book Cliffs Mountains}

Our study took place in Grand County, Utah, on private land and TSRA in the South Book Cliffs Mountains of Utah (Fig. 1). The Book Cliffs Mountains are located in a remote area of eastern Utah. Steep canyons with riparian areas located in the can- 




Figure 1. Location of the study site in Grand County, Utah.

yon bottoms typify the topography of the Book Cliffs. No paved roads run through the area, but there are some unimproved dirt roads. From 1990 to 2009, human population, energy development, and recreational pressures in the area have changed little. Hunting occurred in the area prior to and after 1990.

Average annual mean precipitation for the area is 9.1 inches, but precipitation in the mountainous areas of Utah like the Book Cliffs can vary widely due to seasonal thunder showers. The 2010 UDWR Range Trend Report indicated that 1990 and 2009 were moderate to extreme drought years in the area. The Palmer drought index was -3.5 in 1990 and -1.5 in 2009. Precipitation data were collected at the top of Bogart Canyon from 2 February to 24 September 1990, and was 8.3 inches with 3.5 inches falling from 24 July to 24 September 1990.

\section{Vegetation Monitoring and Repeat Photography}

Cattle grazed meadows on private land along riparian corridors early in the summer and were moved to TSRA upland pastures in late July 1990. On 26-27 July 1990 we placed utilization cages at 12 locations in She Canyon and along West Willow Creek, Utah (Fig. 2). Utilization cages prevented elk and other wildlife species from grazing the vegetation under each cage. We marked uncaged areas adjacent to cages. On 25-26 September 1990 we clipped vegetation from caged and uncaged plots. After clipping, plant material was placed in paper bags and air-dried to a constant weight, and weights were recorded. The difference in weight of the vegetation in caged and uncaged plots represented the amount of forage used by elk or other wildlife over 61 days from 25-26 July to 25-26 September 1990.

In addition to the clipping study, photos were taken at each survey location on 25-26 July and 25-26 September
1990 and 28-29 July 2009. This allowed us to compared photos from 1990 and 2009 as a method of documenting the changes in the area since the removal of cattle.

\section{How Much Forage Did Wildlife Eat?}

Nearly twice as much forage was clipped from caged as uncaged plots (Table 1). Caged plots contained an average of 2,014 pounds per acre of forage, whereas uncaged plots contained 1,076 pounds per acre of forage. ${ }^{i}$ On average, elk ate 938 pounds per acre of forage from each of the 12 locations or nearly $50 \%$ of the available forage. Repeat photos in Figure 3 are of Big Meadow, the site with the greatest utilization (65\%) by wildlife. Photos in Figure 4 were taken at Supply Canyon, the site with the least amount of utilization (14\%).

\section{Years Later}

In July and September 1990, we saw large numbers of elk in both She Canyon and along West Willow Creek. In September 1990, we also saw numerous elk wallows in the canyon bottoms. Very different conditions were encountered when we returned in 2009. We saw no elk and very little recent sign of elk in the area during the two and a half days we rode horseback through the area. In addition, the vegetation at the survey locations showed no sign of use by any large grazing ungulate.

Repeat photos taken of the survey sites showed forage conditions as cattle left the pasture (26-27 July 1990), 61 days later on 25-26 September 1990, and 19 years later on 28-29 July 2009 (Figs. 3 and 4). Dense stands of mature annual and perennial grasses, including basin wildrye (Leymus 


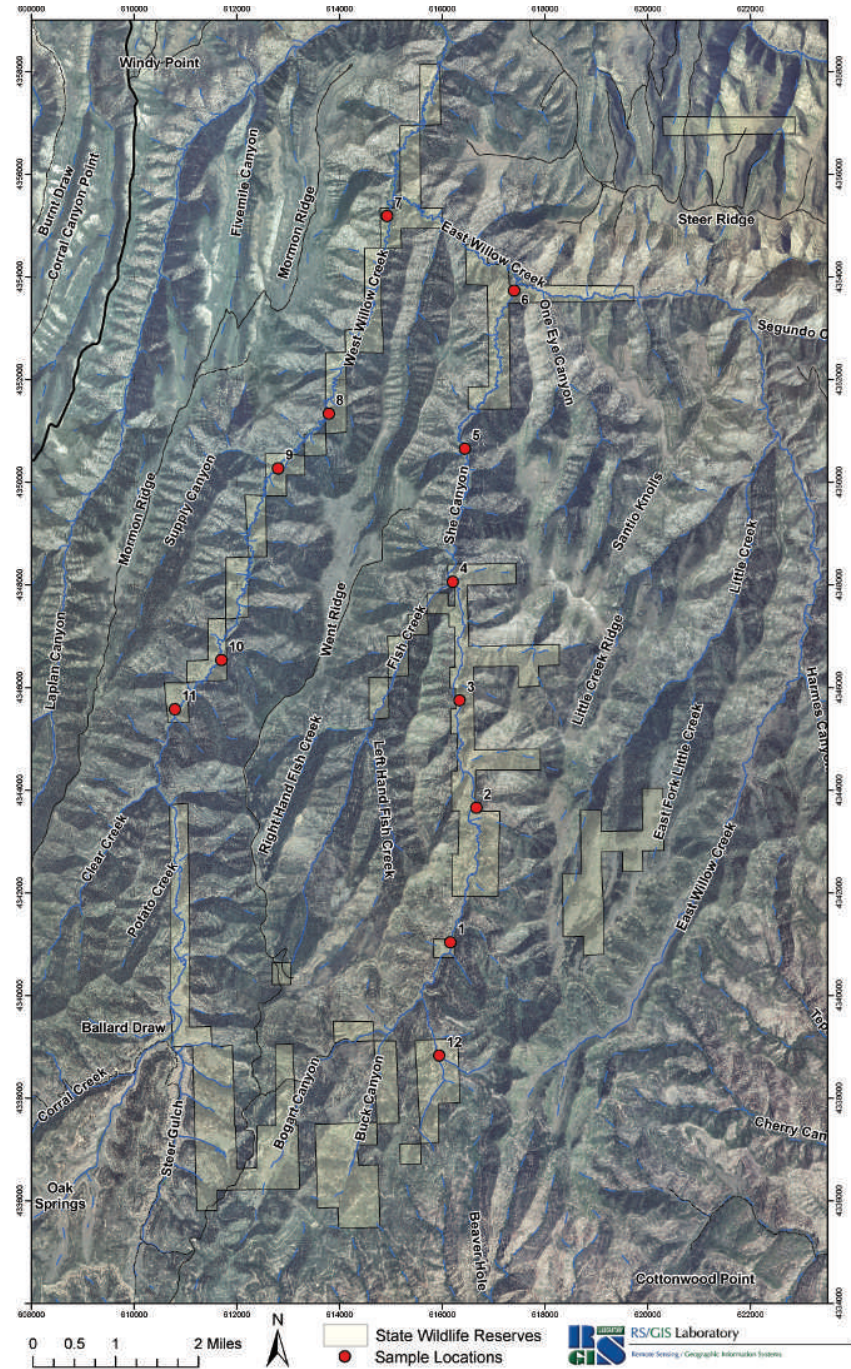

Figure 2. Location of utilization cages and repeat photos in She Canyon and along West Willow Creek.

cinereus), dominated the bottoms. Weeds, such as thistles, were also visible in some areas.

\section{Nutritional Changes in the Areas}

The nutritional quality of the mature forage in the meadows observed in the July 2009 photos was certainly much lower in nutrient content than the vegetative regrowth pictured in the July or September 1990 photos. As plants mature, nutrient (nitrogen, minerals, and energy) content of both native and nonnative plants declines. ${ }^{1-3}$ All plants display a decline in nutritive value as they mature, but to different degrees, different rates, and varying patterns. ${ }^{1}$ Ganskopp and Bohnert ${ }^{3}$ analyzed seven range grasses over the growing season and found that by late July most of these grasses did not contain enough protein to meet requirements of cattle.

Vegetative regrowth is always superior to more mature forage. When cattle grazed grasses in spring $(50 \%$ utilization), Ganskopp et al. ${ }^{4}$ reported that the subsequent regrowth was $77 \%$ higher in protein and $20 \%$ higher in digestibility than ungrazed grasses. In a follow-up study, spring grazing increased the protein content of late summer and early fall vegetation by $56-150 \%$ and digestibility by $17-32 \%$ depending on plant species and growing conditions. ${ }^{5}$

Changes in forage composition can occur when grazing management changes in an area. In 2009 five of the survey sites show increases in the amount basin wildrye plants. In the 1990 photos, few or no basin wildrye plants were visible in these same sites. Unfortunately, basin wildrye is not a preferred plant species at least for cattle and may not be for elk. When given a choice among eight varieties of grass, cattle selected only $5-6 \%$ of their bites from basin wildrye plants. ${ }^{6}$

In 2009 many of our sites contained standing dead material that grew in previous years, which is a sign the area has not been grazed recently and affects the nutritional quality and preference for grasses. When standing dead stems made up a mere $4 \%$ of a plant's biomass, cattle grazed only $45 \%$ of those bunchgrass plants, but $75 \%$ of the grasses were grazed if they contained no standing dead stems. ${ }^{7}$ Bunchgrasses with one, two, and three mature stems were, respectively, $8 \%, 20 \%$, and 32\% less likely to be grazed than plants with no dead stems, and these same treatments had, respectively, 35\%, 39\%, and 60\% less material removed by cattle than plants without dead stems. ${ }^{8}$

Range trend studies from the Utah Division of Wildlife Resources (UDWR) indicate a decline in forage quality in the South Book Cliffs by 2010. Five years after cattle were remove from the study area, the 1995 UDWR Range Trend Study ${ }^{9}$ reported excellent vegetative cover for forage and erosion control in the meadow where She and Bogart Canyons meet. However, the 2010 UDWR Range Trend Study ${ }^{10}$ for the South Book Cliffs stated that species composition of the herbaceous understory was declining in quality, and annual grasses such as cheatgrass were increasing.

\section{Cattle Grazing and Elk Habitat}

Much of the literature on cattle-elk interactions concludes that properly managed cattle grazing can increase elk numbers. One long-term study in Oregon ${ }^{11}$ removed cattle from an elk winter range in 1961 . Over the next three years, elk numbers increased from 120 to 320 , but forage on the range became increasingly fibrous and poor in nutritional quality. In 1964 cattle were reintroduced to the area, and a management plan was implemented to control the time, timing, and intensity of cattle grazing. Ten years after the plan was implemented, the average elk count on the winter range was 1,191 head. The estimated number of elk-days on the site increased from 15,980 to 168,957 . Elk also increased the length of time they used the site during winter by $78 \%$. During this same 10 -year period, the ecological condition of the range improved and animal unit months more than doubled. In 1996, 32 years after the 1964 cattle management plan was implemented, Moser and Witmer $^{12}$ sampled vegetation from grazed areas and ungrazed exclosures (50 to 100 acres) built between 1982 and 1991. They found no differences in herbaceous vegetative cover, species 
Table 1. Amount of forage clipped on 25 September 1990 from caged and uncaged plots (pounds per acre)

\begin{tabular}{|c|c|c|c|c|c|}
\hline Plot no. & Location & Caged & Uncaged & Difference & Utilization \\
\hline 1 & Riviguts & 1,895 & 1,066 & 829 & $43 \%$ \\
\hline 2 & Deep Wash & 2,487 & 1185 & 1,302 & $52 \%$ \\
\hline 3 & Big Meadow & 2,724 & 948 & 1,776 & $65 \%$ \\
\hline 4 & Fish Creek & 1,895 & 948 & 947 & $50 \%$ \\
\hline 5 & Rope 'em Flat & 1,777 & 829 & 948 & $53 \%$ \\
\hline 6 & Byron's & 3,672 & 2,014 & 1,658 & $45 \%$ \\
\hline 7 & West Willow Fence & 1,185 & 829 & 356 & $30 \%$ \\
\hline 8 & Steamboat Rock & 1,421 & 948 & 473 & $33 \%$ \\
\hline 9 & Supply Canyon & 1,658 & 1,421 & 237 & $14 \%$ \\
\hline 10 & West Willow & 1,658 & 1,066 & 592 & $36 \%$ \\
\hline 11 & Clear Creek & 1,895 & 829 & 1,066 & $56 \%$ \\
\hline 12 & Head She Canyon & 1,895 & 829 & 1,066 & $56 \%$ \\
\hline Average & & 2,014 & 1,076 & 938 & $44 \%$ \\
\hline
\end{tabular}

richness, biomass, or diversity between grazed sites and ungrazed exclosures. Furthermore, elk numbers increased from 1,191 in 1974 to approximately 2,000 by 1995 .

Grover and Thompson ${ }^{13}$ demonstrated that elk preferred pastures in spring that were grazed by cattle the previous fall. In another study comparing burning or cattle grazing, elk preferred burned sites to those grazed by cattle but preferred grazed sites to untreated sites. Grazing was not as effective in reducing the accumulated plant litter as burning; however, cattle grazing created a mosaic of heavy to lightly grazed areas while maintaining litter cover on the soil surface. ${ }^{14}$

Several studies have demonstrated that grazing in spring by cattle or sheep can increase forage quality (crude protein and digestibility) in late summer and fall. ${ }^{4,5,15}$ Interestingly, elk alone may have very different impacts on forage nutrition than cattle or the combination of both species. Researchers in Oregon found that early summer grazing by cattle but not elk had a beneficial impact on the nutritional quality of late summer diets for cattle, elk, and deer. ${ }^{16}$

Short and $\mathrm{Knight}^{17}$ concluded that short-duration grazing cattle in fall can improve habitat for deer and elk the following spring and summer. Grazing treatments reduced the amount of unpalatable standing dead vegetation and increased the percentage of green grass on rangeland. Frisina ${ }^{18}$ suggested that cattle grazing in spring within a rest-rotation grazing system could attract elk to public game ranges and away from adjacent private lands because elk prefer pastures previously grazed by livestock.

It is difficult to pinpoint the exact reason elk stopped foraging in our study area. Little has changed since 1990 in this remote area of Utah except the removal of cattle. The decline in elk use is unlikely a result of fewer elk in the area because estimated elk counts in the South Book Cliffs were 185 in 1993, 158 in 2000, 789 in 2007, and 519 in 2009. Since neither researchers nor ranchers saw any elk, or signs of elk, when they rode through the area in 2009 and the bottoms were overgrown with old decadent forage, it is likely that elk have not grazed in the TSRA for a long time.

When cattle and elk graze the same rangeland, it should not be assumed that grazing by cattle is always detrimental to elk. Quite the contrary, numerous studies conclude that properly managed cattle grazing can improve forage quality and use by elk either in the fall or in the spring. ${ }^{11,13-18}$ Alt et al. ${ }^{19}$ reported that when cattle were removed for 21 years from a 7,000-acre wildlife management unit (WMU), elk continued to trespass 

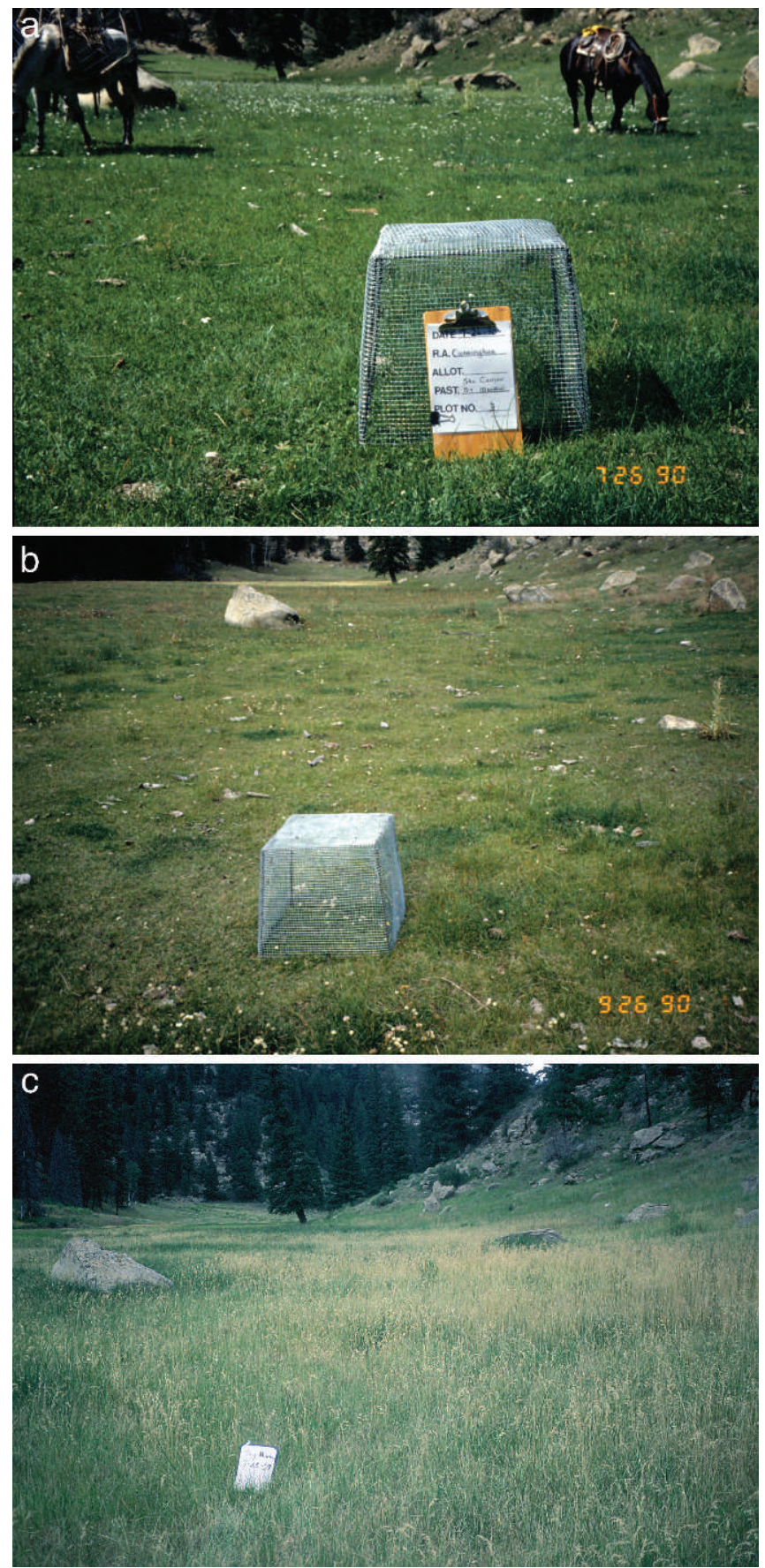

Figure 3. Big Meadow, 26 July 1990 (a), 26 September 1990 (b), and 28 July 2009 (c).

onto adjacent rangeland graze by cattle. Hazing efforts and improving forage quality by mowing or fertilization on the WMU were unsuccessful at keeping elk on the wildlife unit. Finally, wildlife managers reintroduced grazing to resolve the conflict.

Cattle grazing that occurred during 1990 on TSRA likely improved forage quality for elk by keeping forage in an immature state. Summer regrowth is highly nutritious and far superior to the more mature vegetation that now stands in the canyon bottoms and receives little if any grazing by elk.
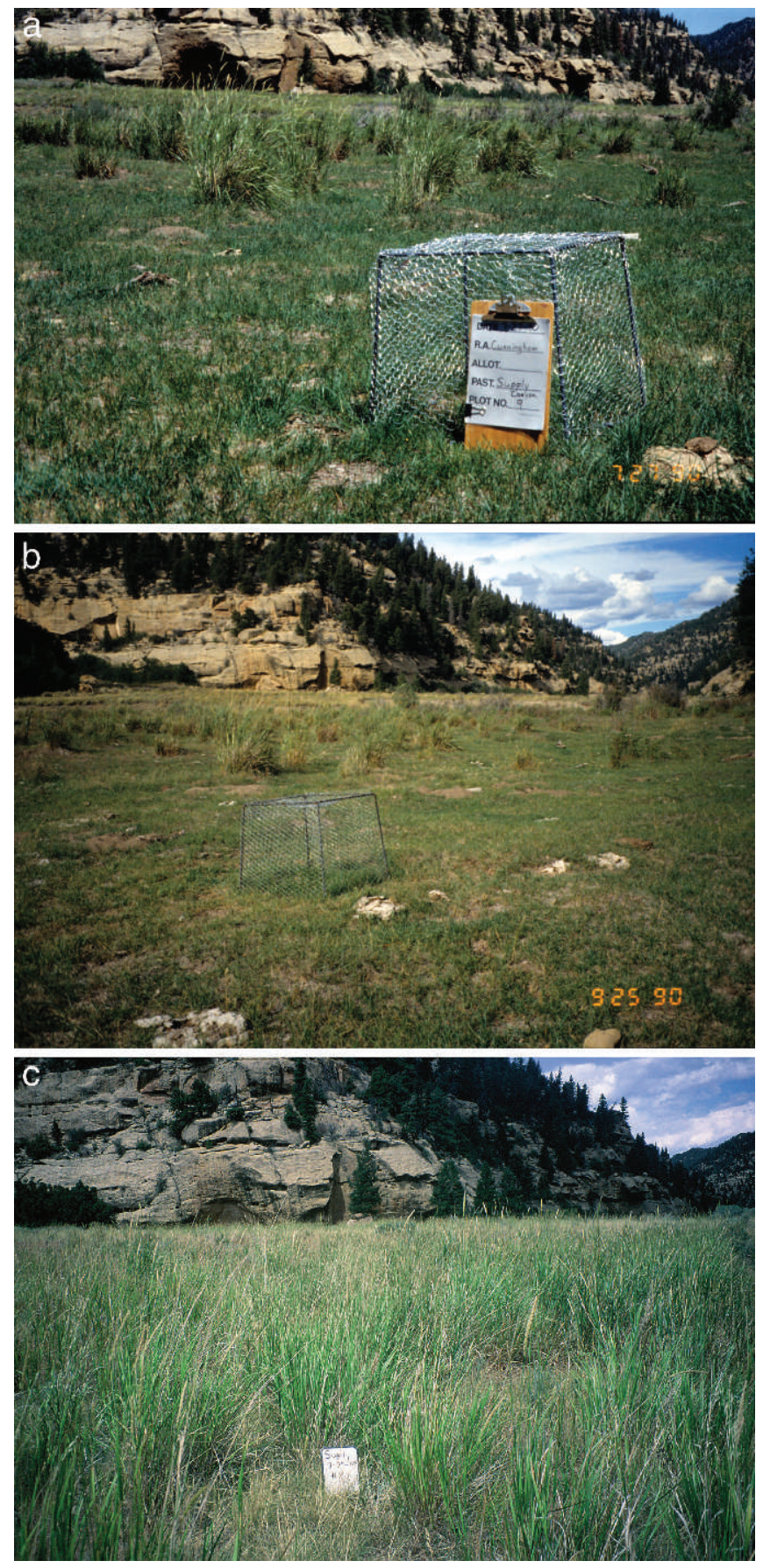

Figure 4. Supply Canyon, 27 July 1990 (a), 25 September 1990 (b), and 29 July 2009 (c)

Removing cattle grazing likely changed an area that once provided elk with high-quality forage to an area with large quantities of poor-quality forage.

Unlike cattle grazing, elk grazing is less likely to adequately condition forage. Elk cannot be managed like cattle. Elk cannot be constrained to a limited area to produce a desired level of grazing at a specific time of year. Elk also tend to use preferred plants and locations first, and their grazing is generally distributed over a much larger area than most managed 
cattle grazing. Wildlife use of formerly preferred areas may gradually decline over time. Forage in unused areas becomes more mature until the entire area is converted to forage with a large percentage of standing dead material, low in nutrients and not preferred by elk. Elk then move on to areas where more nutritious forage is available.

Our study in the Book Cliffs in She Canyon and along West Willow Creek in TSRA provides additional evidence that cattle may improve habitat and nutrition for elk. Whether elk no longer use this area due to the removal of livestock or for some other reason, elk are unlikely to return to the area unless fire, mechanical treatments, or grazing changes the forage quality in the area. Wildlife agencies or any other manager wishing to improve the forage nutritional environment for ungulate wildlife may consider the intelligent application of livestock grazing.

\section{References}

1. Cogswell, C., and L. D. Kamstra. 1976. The stage of maturity and its effect upon the chemical composition of four native range species Journal of Range Management 29:460-463.

2. Kilcher, M. R. 1981. Plant development, stage of maturity and nutrient composition. Journal of Range Management 34:363364.

3. Ganskopp, D., and D. Bohnert. 2001. Nutritional dynamics of 7 northern Great Basin grasses. Journal of Range Management 54:640-647.

4. Ganskopp, D., T. SvejCar, and M. Vavra. 2004. Livestock forage conditioning: bluebunch wheatgrass, Idaho fescue, and bottlebrush squirreltail. Journal of Range Management 57:384-392.

5. Ganskopp, D., L. Aguilera, and M. Vavra. 2007. Livestock forage conditioning among six northern Great Basin grasses. Rangeland Ecology Eं Management 60:71-78.

6. Ganskopp, D., B. Myers, S. Lambert, and R. Cruz. 1997. Preferences and behavior of cattle grazing 8 varieties of grasses. Journal of Range Management 50:578-586.

7. Ganskopp, D., R. Angell, And J. Rose. 1992. Response of cattle to cured reproductive stems in a caespitose grass. Journal of Range Management 45:401-404.

8. Ganskopp, D., R. Angell, and J. Rose. 1993. Effect of low densities of senescent stems in crested wheatgrass on plant selection and utilization by beef cattle. Applied Animal Behaviour Science 38:227-233.
9. Utah Division of Wildlife Resources. 1995. Trend study 10-23-00. Available at: http://wildlife.utah.gov/range/pdf/ wmu10/10-23.pdf. Accessed 7 November 2012.

10. Utah Division of Wildlife Resources. 2011. Utah big game range trend studies 2011: northern region. Available at: http://wildlife.utah.gov/range/pdf/Archive\%20Reports/2011\% 20Northern.pdf. Accessed 7 November 2012.

11. Anderson, E. W., And R. J. Scherzinger. 1975. Improving quality of winter forage for elk by cattle grazing. Journal of Range Management 28:120-125.

12. Moser, B.W., and G. W.Witmer. 2000. The effects of elk and cattle foraging on the vegetation, birds and small mammals of the Bridge Creek Wildlife Area. International Biodeterioration E Biodegradation 45:151-157.

13. Grover, K. E., And M.J. Thompson. 1986. Factors influencing spring feeding site selection by elk in the Elkhorn Mountains, Montana. Journal of Wildlife Management 50:466-470.

14. Jourdonnais, C. S., And D. J. Bedunah. 1990. Prescribed fire and cattle grazing on an elk winter range in Montana. Wildlife Society Bulletin 18:232-240.

15. Clark, P. E., W. C. Kruger, L. D. Bryant, and D. R. Thomas. 2000. Livestock grazing effects on forage quality of elk winter range. Journal of Range Management 53:97-105.

16. Damiran, D., T. Delcurto, S. L. Findholt, G. D. Pulsipher, AND B. K. Johnson. 2003. Influence of previous cattle and elk grazing on the subsequent quality and quantity of diets for cattle, deer and elk grazing late-summer mixed-conifer rangelands. Proceedings of the Western Section of the American Society of Animal Science 54:320-324.

17. Short, J. J., And J. E. Knight. 2003. Fall grazing affects big game forage on rough fescue grasslands. Journal of Range Management 56:213-217.

18. Frisina, M. R. 1992. Elk habitat use within a rest-rotation grazing system. Rangelands 14:93-96.

19. Alt, K. L., M. R. Frisina, and F. J. King. 1992. Coordinated management of elk and cattle, a perspective: Wall Creek Wildlife Management Area. Rangelands 14:12-15.

Authors are Extension Assistant Professor, beth.burritt@usu.edu (Burritt), and Extension Rangeland Specialist (Banner), Department of Wildland Resources, Utah State University Extension, Logan, UT 84322, USA. 